\title{
Viability Testof Lemongrass Extract (Cymbopogon Citratus) on BHK-21 Fibroblast Cell Culture
}

\author{
Shafira Kurnia Supandi ${ }^{1}$, Yoshua Christian Michael ${ }^{1}$, Lambang Bargowo ${ }^{1}$ \\ ${ }^{1}$ Department of Periodonsia Dentistry, Faculty of Dental Medicine, Universitas Airlangga, Mayjen, \\ Prof. Dr. Moestopo Street, Surabaya, Indonesia, 60132
}

\begin{abstract}
Background: Lemongrass are found in Indonesia thus it lemongrass can be used as an alternative in healing inflammation by conducting a preliminary study in the form of BHK-21 fibroblast cell viability test after 24 hours of extract lemongrass.

Objective: To determine the viability of extract lemongrass against BHK-21 fibroblast cell cultures. Method: BHK-21 fibroblast cells were taken from neonatal hamsters' kidneys and planted in 96 well plates. Extracts lemongrass with concentrations of $100 \%, 50 \%, 25 \%, 12.5 \%, 6.25 \%, 3.13 \%$ and $1.56 \%$ were included in each well prepared and incubated for 24 hours. MTT Assay was performed to see the viability of extract lemongrass on fibroblast cells.
\end{abstract}

Results: Extract lemongrass viable against BHK-21 fibroblast cells at a concentration of $100 \%$. There is a decrease in viability at concentrations of $50 \%$ to $1.56 \%$.

Conclusion: The $100 \%$ concentration showed the highest viability of BHK-21 fibroblast cells and extract lemongrass had potential in wound healing.

Keywords: Extract lemongrass, BHK-21 fibroblast cells, viability.

\section{Introduction}

Periodontal disease is a chronic bacterial infection characterized by persistent chronic inflamation, connective tissue damage and bone destruction. Periodontal disease has characteristic multifactors, because interaction of plaque, microbial and host will increase host inflammantory response. The prevalence of periodontal disease is $10-60 \%$ in adults in the world ${ }^{1,2}$. The Javanese are the largest ethnic group in Indonesia. There are $87.84 \%$ of Indonesia's population who

\section{Corresponding Author:}

Shafira Kurnia Supandi

Department of Periodonsia Dentistry, Faculty of Dental Medicine, Universitas Airlangga, Mayjen, Prof. Dr.

Moestopo Street, Surabaya, Indonesia, 60132

e-mail: shafirakurnias@gmail.com suffer from dental disease also experience periodontal abnormalities $^{3,4}$.

Periodontal tissue damage can be caused by a variety of factors, one of the most common causes is gingivitis. Gingivitis is a periodontal disease caused by plaque. Gingivitis has clinical symptoms such as redness, bleeding on probing, contour changes and the presence of calculus or plaque without evidence of loss of radiography in the alveolar bone ${ }^{5}$.

Injuries are defined as damage or loss of continuity in skin or tissue integrity ${ }^{6}$. Injuries that occur in the gingiva can heal clinically within a few weeks, but complete healing and formation of gingival fibers take several months ${ }^{5}$. The wound healing process can be seen from several parameters, namely epithelialization, the number of polymorphonuclear cells (PMN) which increases in the inflammatory phase and the increase in fibroblast cell counts and density of collagen fibers ${ }^{7}$. Fibroblast cells 
are very important to indicate that the healing process is ongoing. Fibroblast cells will start to look a lot on the second day. Fibroblast cells are an important component because they stimulate the formation of collagen ${ }^{8}$. Baby Hamster Kidney-21 (BHK-21) is a cell culture derived from the main culture of the kidney tissue of neonatal hamsters, sheia. BHK-21 was first used in 1960. BHK-21 is widely used in research, especially in the biomedical field ${ }^{9}$.

The plants used for the healing process are lemongrass or other names cymbopogon citratus. Lemongrass phytochemical test results shows that it contains alkaloids, carbohydrates, saponins, tannins, glycosides, proteins and terpenoids ${ }^{10}$. Lemongrass are also one of the plants used for anti-bacteria ${ }^{11}$. Lemongrass have several ingredients that can speed up the healing process of inflammation. Lemongrass also have several uses, among others, as antifungal, antiseptic, antibacterial, antipyretic, antidepressant, antimicrobial and anti-carcinogenic ${ }^{12}$.

Lemongrass must be tested first about the viability and composition of the lemongrass. This is needed to find out what content is contained in it and whether it is suitable for use in experimental animals or not. Based on the description of the background, the researchers would like to conduct further research on the viability of lemongrass extracts against BHK-21 fibroblast cell cultures.

\section{Materials and Method}

This type of research was an experimental laboratory. This research was conducted at the Veterinaria Fatma Center (PUSVETMA) and the Industrial Research and Consultation Center (BPKI) Laboratory. The implementation of this research begins August - October 2018.

The ingredients used were: lemongrass extract (cymbopogoncitratus), BHK-21 culture cell lines from PUSVETMA, culture media containing Eagle's minimum essential medium (MEM), Dimethyl Sulfoxide (DMSO), MTT, Phosphate Buffer Saline (PBS) $(50 \mathrm{mg}$ MTT and $10 \mathrm{~mL}, \mathrm{PBS}), 96 \%$ ethanol and aquadest. Tools used: filter paper, scales, blenders, pumpkin glass, Rotatory evaporators, test tubes, shelves, beaker glass, ovens, scales, plastic warp, shakers with magnetic stirrers, BIOH-T Proline micro-pipets 20-200 $\mu \mathrm{L}$, small tubes, 96-well plate Falcon 3072, conical tube ep. T.I.P.S $200 \mu \mathrm{L}$, roux bottle, incubator, micro microscope and ELISA reader

Extract Lemongrass: Lemongrass were dried in an oven with a temperature of $50^{\circ} \mathrm{C}$. Dried lemongrass milled using a blender. Lemongrass powder was weighed. Lemongrass were put into a glass beaker and added ethanol to $2.5 \mathrm{~L}$. Lemongrass in beaker glass are rotated using a shaker. Filtering was completed, the pulp was inserted into the beaker glass. Given an ethanol solution of $2.5 \mathrm{~L}$, then rotated using a shaker. Filtered, the filter results were combined with the first filter results. The filter results were inserted into the rotatory evaporator. Evaporated used waterbath.

\section{MTT Test on BHK-21 Fibroblast Cell Culture}

The MTT test was performed by using BHK21 fibroblast cells. Extraction of lemongrass were made at BPKI. The MTT test was conducted in accordance with the PUSVETMA laboratory procedure. After that, the samples used in this study were divided into nine groups, cells treated with lemongrass extract $100 \%$, $50 \%, 25 \%, 12.5 \%, 6.25 \%, 3.13 \%, 1.56 \%$, cell control containing BHK-21 fibroblast cells and media controls containing MEM. Viability, number of living cells, were then observed by calculating CD90 with MTT assay (3- (4,5-dimethylthiazole-2-yl) -2,5-diphenyltetrazolium bromide). Their absorption was indicated by purplish blue from formazan read using immunosorbent assays enzyme-linked assay (ELISA) with a wavelength of $550-620 \mathrm{~nm}$. The percentage of live cells was measured using the following formula :

$$
\% \text { of live cells }=\frac{\text { Treatment }+ \text { Medi } i}{\text { Cell }+ \text { Media }}
$$

Note: $\%$ of live cells $=$ Percentage of live cell count after the test Treatment $=$ Optical density value of formazan in each sample after the test Media = Optical density value of formazan on media Cell = Optical density value of formazan on control cells. Control cell as a positive control in the culture medium is considered to have a live cell percentage of $100 \%$.

\section{Results}

The average optical density (OD) of cell control, media control and each concentration to be tested were in accordance with table 1.

Table 1 Optical density mean values for BHK-21 fibroblast cells in the treatment and control groups

\begin{tabular}{|l|c|c|}
\hline Group & n & Mean \\
\hline Control media & 4 & 0.06 \\
\hline Control sel & 4 & 0.426 \\
\hline
\end{tabular}




\begin{tabular}{|l|c|c|}
\hline Group & n & Mean \\
\hline $100 \%$ & 4 & 0.428 \\
\hline $50 \%$ & 4 & 0.309 \\
\hline $25 \%$ & 4 & 0.192 \\
\hline $12.5 \%$ & 4 & 0.128 \\
\hline $6.25 \%$ & 4 & 0.08 \\
\hline $3.13 \%$ & 4 & 0.076 \\
\hline $1.56 \%$ & 4 & 0.099 \\
\hline
\end{tabular}

Table 2. The percentage value of live BHK-21 fibroblast cells with concentrations of lemongrass extract.

\begin{tabular}{|c|c|c|}
\hline Lemongrass Extract & n & \% of live cells \\
\hline $100 \%$ & 4 & $100.41 \%$ \\
\hline $50 \%$ & 4 & $75.93 \%$ \\
\hline $25 \%$ & 4 & $51.85 \%$ \\
\hline $12.5 \%$ & 4 & $38.68 \%$ \\
\hline $6.25 \%$ & 4 & $28.89 \%$ \\
\hline $3.13 \%$ & 4 & $27.98 \%$ \\
\hline $1.56 \%$ & 4 & $32.72 \%$ \\
\hline
\end{tabular}

It was known that the percentage of living cells from a concentration of $100 \%$ lemongrass extract up to $1.56 \%$ according to table 2 .

Statistical Analysis: The research data was tested by using the Kolmogorov-Smirnov Test with the results of all groups having a value greater than 0.05 . The research data was tested by using Levene's Test with the results of 0.006 . The research data was tested by using the Kruskal Wallis Test with the results of 0,000 . The results of the research data were tested by the MannWhitney test between the two groups. All groups had significant differences except the concentration of $25 \%$ with a concentration of $1.56 \%$, concentration of $12.5 \%$ with a concentration of $1.56 \%$, concentration of $6.25 \%$ with a concentration of $3.13 \%$, concentration of $6.25 \%$ with media control and concentration of $3.13 \%$ with media control.

\section{Discussion}

This study aims to determine the effect of lemongrass extract on the viability of BHK-21 fibroblast cells. It is known that lemongrass are medicinal plants that are easily found in Indonesia. The use of medicinal plants especially those used in the oral cavity must have minimal side effects, biocompatible and low toxicity ${ }^{13}$. This study uses lemongrass because lemongrass are often used to cure inflammation due to pathology
${ }^{14}$.Making lemongrass extract is done by maceration method and identified. The active ingredients contained in lemongrass extract are other flavonoids: $3.66 \%$, tannins: $1.06 \%$, saponins: $2.16 \%$, essential oils $2.05 \%$ and geraniol: $8.13 \%$.

Moreover, cultured BHK21 fibroblast cells in the MTT assay were used due to several reasons; first, their passage can be 50-70 times; second, their cell growth rate is high; and third, their cell integrity can be maintained. BHK21 has been widely used in dentistry field for the viability test ${ }^{15}$. MTT assay is absorbed into living cells then broken down through a reduction reaction by reductase enzymes in the mitochondrial respiration chain into formazan soluble in a purple solvent. DMSO is added to stop the enzymatic reaction and dissolve the formazan so that the purple color of the formazan can be read its absorbance spectrophotometrically with ELISA reader. The absorbance represents the number of living cells. The stronger the purple color intensity is, the higher the absorbance will be. In other words, this suggests that the more MTT assay is absorbed into living cells can lead to more formazan formation. Consequently, this absorbance can be used to calculate the percentage of living cells as cell response ${ }^{16}$.

In addition, a substance, according to Heravi et al.,${ }^{17}$ on the toxicity parameters of CD90, can be said to be toxic if the percentage of living cells after exposure to the substance is $<90 \%$. The viability percentage of fibroblasts after the administration of extractlemongrass was $100.41 \%$, higher than $90 \%$ in this research. As a result, the extractlemongrass can be considered as a nontoxic substance.

Lemongrass extracts have concentrations of flavonoids, tannins, saponins, essential oils and geraniols which do not reach $10 \%$. When flavonoids, tannins, saponins and geraniols are given at low concentrations, they can stimulate the viability of BHK21 fibroblast cells. Flavonoids and geraniol will have antioxidant effects on cells so that cells will become viable $^{18,19}$. Tanin will have a high affinity effect with proteolytic enzymes thus the tannin will be bound to proteolytic enzymes. This causes proteolytic enzymes to be unable to lysis a cell and cause the cell to become viable $^{6}$. Saponins have natural anti-microbial properties thus saponins can neutralize proteolytic enzymes. The absence of proteolytic enzymes results in no component to destroy the fibroblast cell extracellular matrix, hence the cell becomes viable ${ }^{20}$. 
Conflict of Interest: There is no conflict interest

Source of Funding: This study is self-funded

Ethical of Clearance: This study was approved by Ethical Commision of Health Research Faculty of Dental Medicine Universitas Airlangga

\section{Conclusion}

The conclusion of this study is that lemongrass extract at a concentration of $100 \%$ can maintain the viability of BHK-21 fibroblast cells.

\section{References}

1. Siyam SNL, Nurhapsari A, Benyamin B. Pengaruh Stimulasi Permainan Ular Tangga tentang Gingivitis terhadap Pengetahuan Anak Usia 8-11 Tahun Studi terhadap Siswa SD Negeri Kuningan Kuningan 04, Kecamatan Semarang Utara. Odonto Dent J. 2015;2(1):25-8.

2. Grønkjær LL. Periodontal disease and liver cirrhosis: A systematic review. SAGE open Med. 2015;3:2050312115601122.

3. Palupi R, Juzika O, Romadhoni SF. Impact of social support on the periodontal health among population of pregnant women in Javanese ethnic group. Indian $\mathrm{J}$ Public Heal Res Dev [Internet]. 2019;10(10):1046-50. Available from: https://www.scopus.com/inward/record. uri?eid $=2-\mathrm{s} 2.0-85078016031 \quad \& \quad$ doi $=10.5958 \%$ 2F0976-5506.2019.02962.0 \& partnerID $=40 \& \mathrm{md}$ $5=\mathrm{d} 5 \mathrm{de} 094 \mathrm{bbc} 21 \mathrm{c} 03 \mathrm{a} 8 \mathrm{a} 9 \mathrm{cbd} 676 \mathrm{cb} 53 \mathrm{e} 37$

4. SusantoH,Nesse W, Kertia N, Soeroso J, VanReenen YH, Hoedemaker E, et al. Prevalence and severity of periodontitis in indonesian patients with rheumatoid arthritis. J Periodontol [Internet]. 2013;84(8):106774. Available from: https://www.scopus.com/ inward/record.uri?eid=2-s2.0-84882287325 \& doi $=10.1902 \% 2$ Fjop. $2012.110321 \&$ partnerID $=40$ $\&$ md5=a23857c6c55c93d2f1daedc14085acfc

5. Newman MG, Takei H, Klokkevold PR, Carranza FA. Carranza's clinical periodontology. Elsevier health sciences; 2011.

6. Radafshar G, Ghotbizadeh M, Saadat F, Mirfarhadi $\mathrm{N}$. Effects of green tea (Camellia sinensis) mouthwash containing $1 \%$ tannin on dental plaque and chronic gingivitis: a double-blinded, randomized, controlled trial. J Investig Clin Dent. 2017;8(1):e12184.
Medico-legal Update, April-June 2020, Vol. 20, No. 2

823

7. Andreasen JO, Andreasen FM, Andersson L. Textbook and color atlas of traumatic injuries to the teeth. John Wiley \& Sons; 2018.

8. Junqueira LCU, Carneiro J. Histologia básica 12th Edn. 2015;

9. Johnson KC, Yongky A, Vishwanathan N, Jacob NM, Jayapal KP, Goudar CT, et al. Exploring the transcriptome space of a recombinant BHK cell line through next generation sequencing. Biotechnol Bioeng. 2014;111(4):770-81.

10. Devianna T, Purnama A, Purnomo $\mathrm{Y}$, Rizqiawan A. Effects of lemongrass leaf on macrophages after tooth extraction of wistar rat. Biochem Cell Arch [Internet]. 2019;486770. Available from: https://www.scopus.com/ inward/record.uri?eid=2-s2.0-85079398942 \& doi $=10.35124 \% 2$ Fbca.2019.19.S2.4867 \& partnerID $=40 \&$ md5=8322989623530406e9f6163 80 efeb7e6

11. Ewansiha JU, Garba SA, Mawak JD, Oyewole OA. Antimicrobial Activity of Cymbopogon citratus (Lemon Grass) and It's Phytochemical Properties. 2012;

12. Feriyanto YE, Sipahutar PJ, Mahfud M, Prihatini P. Pengambilan Minyak Atsiri dari Daun dan Batang Serai Wangi (Cymbopogon winterianus) Menggunakan Metode Distilasi Uap dan Air dengan Pemanasan Microwave. J Tek ITS. 2013;2(1):F937.

13. Kaomongkolgit R, Jamdee K, Pumklin J, Pavasant P. Laboratory evaluation of the antibacterial and cytotoxic effect of alpha-mangostin when used as a root canal irrigant. Indian J Dent. 2013;4(1):12-7.

14. Francisco V, Costa G, Figueirinha A, Marques C, Pereira P, Neves BM, et al. Anti-inflammatory activity of Cymbopogon citratus leaves infusion via proteasome and nuclear factor- $\kappa \mathrm{B}$ pathway inhibition: Contribution of chlorogenic acid. J Ethnopharmacol. 2013;148(1):126-34.

15. Riss, L T, A R, L A, D S, A H, et al. Cell Viability Assays, Bethesda (MD): Eli Lilly \& Company and the National Center for Advancing Translational Sciences. 2016. 69-84 p.

16. Stockert JC, Blázquez-Castro $\mathrm{A}$, Cañete $\mathrm{M}$, Horobin RW, Villanueva Á. MTT assay for cell viability: Intracellular localization of the formazan product is in lipid droplets. Acta Histochem. 2012;114(8):785-96. 
17. Momen-Heravi F, Balaj L, Alian S, Mantel P-Y, Halleck AE, Trachtenberg AJ, et al. Current method for the isolation of extracellular vesicles. Biol Chem. 2013;394(10):1253-62.

18. Panche AN, Diwan AD, Chandra SR. Flavonoids: an overview. J Nutr Sci. 2016;5.

19. Cho M, So I, Chun JN, Jeon J-H. The antitumor effects of geraniol: Modulation of cancer hallmark pathways. Int J Oncol. 2016;48(5):1772-82.

20. Ashafa AOT, Nafiu MO. Antidiabetic activity and free radicals modulatory potentials of saponinrich extract of Cochlospermum planchonii (Hook Fx. Planch) root in vitro. Comp Clin Path. 2018;27(2):313-20. 